\title{
St James and the Good Shepherd: windows on the landscape
}

\author{
Paul A Addison, designTRIBE, Auckland
}

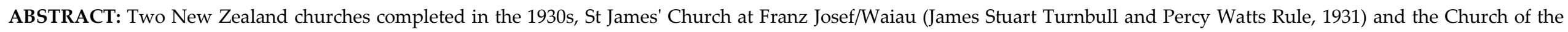

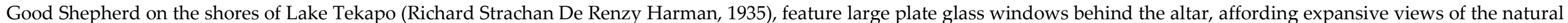

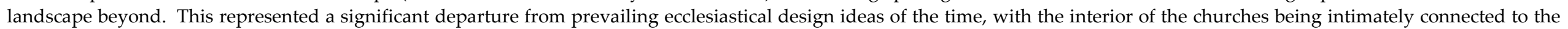

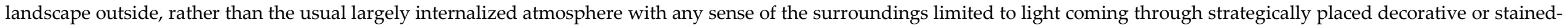

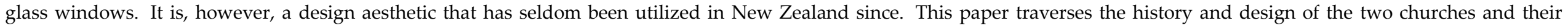

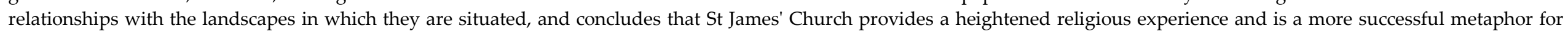
the Christian journey.

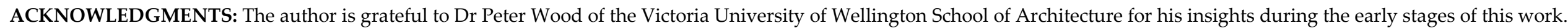

\section{Introduction}

St James' Church in the West Coast village of Franz Josef/Waiau and the Church of the Good Shepherd beside Lake Tekapo, built four years apart in the early 1930s, are just 72 $\mathrm{km}$ from each other as the kuaka flies, on opposite sides of the South Island's main divide, but the shortest journey between them by road is $471 \mathrm{~km}$. Similarly, while the two churches appear to have common design aspects, it will be argued that they provide markedly different religious experiences because of their respective relationships to the landscapes in which they stand.

\section{Locations in the landscape}

The two churches stand in iconic contemporary tourist locations that are also sites of significance to Māori, embedded in
Māori oral traditions. As with societies worldwide in which knowledge of place is or was transmitted orally, iwi Māori imbued tohu whakahirahira (significant landmarks) with cosmogonic pūrakau (stories) as an aid to remembering geographic locations, their properties and resources, and the relationships between them. These stories were an aide memoire, in place of the books and atlases used by societies with a written tradition.

Franz Josef Glacier is known to Māori as Kā Roimata-a-Hinehukatere, literally the tears of Hinehukatere. The name recalls a woman, Hinehukatere, who was a skilled mountaineer, but her beloved, Wawe, did not share her agility, and when the pair were traversing the area, Wawe slipped and plunged to his death. Stricken with grief, Hinehukatere wept profusely, and her tears were frozen by the gods in eternal memory of the tragedy. ${ }^{1}$ The tale also serves to remind those who know the story of the dangers of travelling in that alpine environment.

Given its European soubriquet by the noted geologist Julius von Haast in 1865 in honour of the Austrian emperor, the Franz Josef Glacier/Kā Roimata-a-Hinehukatere has been a significant tourist attraction since the 1880s, given that it is, along with the nearby Fox Glacier/Te Moeka o Tuawe, one of the most accessible glaciers in the world. ${ }^{2}$ Since that

\footnotetext{
1 "Whenua" p 4.

2 Pope \& Pope South Island and Stewart Island p 128; Yarwood "The cold hard truth" n.p.
} 
time, Franz Josef has experienced a series of advances and retreats, but since 2008 it has seen a rapid retreat. ${ }^{3}$

Tekapo, a corruption of Takapō, was one of the many lakes of Te Waipounamu that, according to oral tradition, was formed by Rākaihautū, the captain of the waka Uruao. After landing at Whakatū (Nelson), Rākaihautū led his party down the island, digging the freshwater lakes of the interior with his kō (digging stick). The area around Tekapo was an important mahinga kai (food gathering area), particularly for weka and tuna (eels). ${ }^{4}$

\section{St James' Church, Franz Josef/Waiau}

Established in 1867, the Anglican parish of Ross and South Westland serves most of the West Coast south of Hokitika, but it was not until 1925 that there was deemed to be sufficient need for a dedicated church at Franz Josef/Waiau. The incumbent vicar, the Reverend James Young proposed a church built using local river stones and architect Maurice Guthrie of Christchurch was commissioned to design the building on land

\footnotetext{
3 Yarwood "The cold hard truth" n.p.

${ }^{4}$ Taonui "Canoe traditions" p 8; "Takapō" n.p.
}

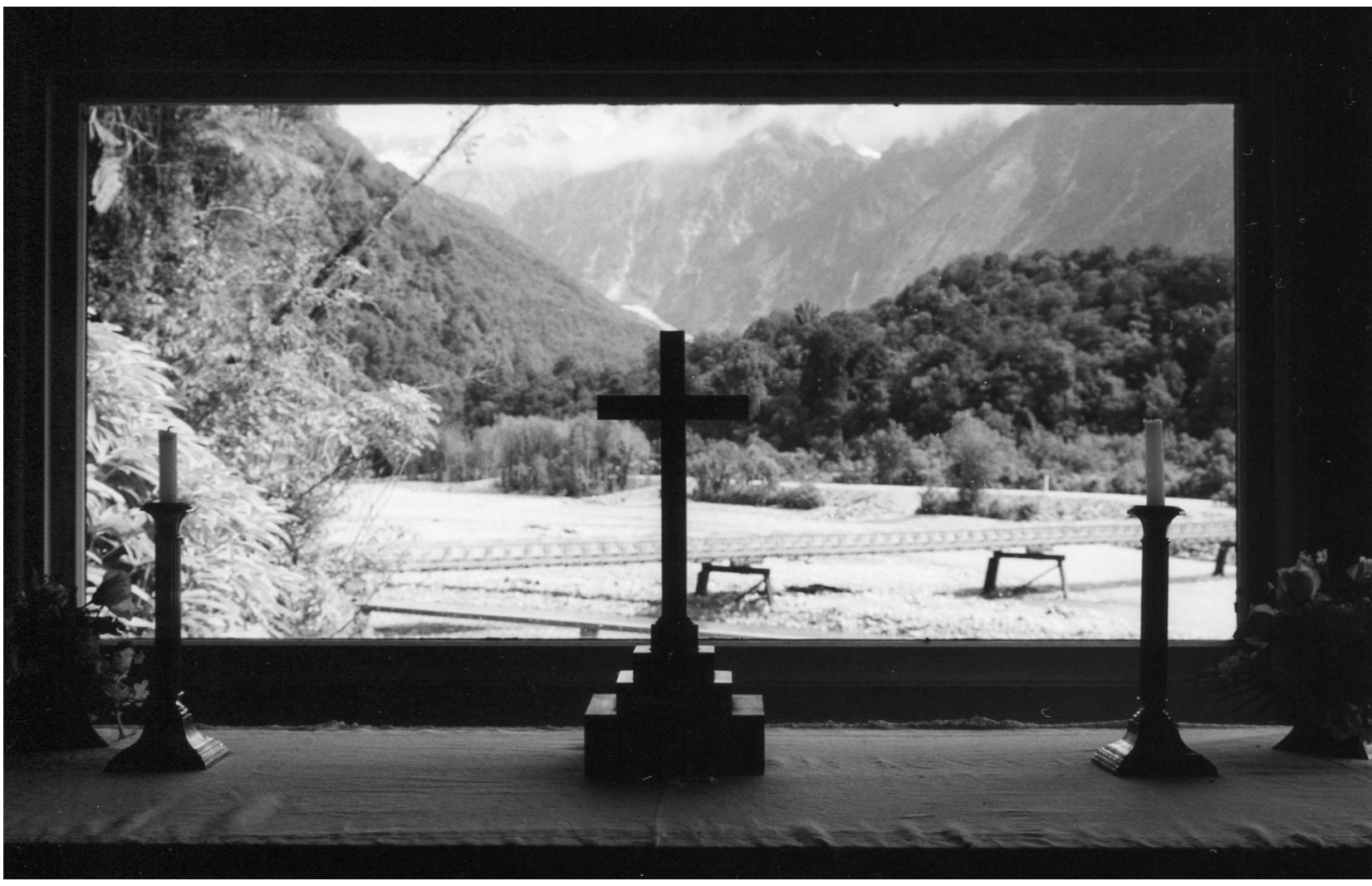

Figure 1: View from St James' Church in 1998 with Franz Josef Glacier / Kā Roimata-a-Hinehukatere visible above the cross. Source: Author.

alongside the Waiho River donated by the Graham family, who were noted mountain guides and ran the nearby Franz Josef Glacier Hotel. The construction cost of Guthrie's design, however, far exceeded the budget of the small congregation of just nine families, and so James Stuart Turnbull and Percy Watts

Rule of Timaru were engaged in 1928 to produce an alternative design. ${ }^{5}$ The Dean of Christchurch, John Awdry Julius, suggested the incorporation of clear windows behind the altar, instead of a traditional reredos, to afford views of the glacier and mountains beyond,

${ }^{5}$ Lovell-Smith "St James Church" n.p. 
and the Reverend Alwyn Keith Warren, by now incumbent of Ross and South Westland (and later Dean and then Bishop of Christchurch), suggested alterations to Turnbull and Rule's plan and was responsible for the interior decoration. ${ }^{6}$

The contract for the construction of the church was let in January 1931 to Bullock and Stewart, and foundation stone was laid the following month, on 3 February, by the governor-general, Lord Bledisloe. ${ }^{7}$ The construction cost of the church was approximately $£ 1000$. Less than three months later, on 26 April 1931, the church was dedicated by the Bishop of Christchurch, Campbell West-Watson, assisted by Reverend James Young (by then incumbent of Hāwera) and Reverend Alwyn Warren. Immediately after the dedication, the first christening in the church took place, with the infant son of Joe Fluerty, a notable mountain guide from local iwi Kāti Māhaki ki Makaawhio, being baptised. ${ }^{8}$

The Tudoresque church, symmetrical in plan, sits in a bush clearing on the western side of

${ }^{6}$ Warren "Waiho Gorge church" p 17.

${ }^{7}$ Lovell-Smith "St James Church" n.p.

8 "Church in the Alps" p 5.
State Highway 6 at the south end of Franz Josef/Waiau village, and overlooking the Waiho River and bridge to the south. It has seating for 100 worshippers. The board-andbatten structure with internal diagonal bracing sits on a foundation of river stones. Orientated along a north-south axis, the church has a castellated belltower at the northern end with the main entrance from the east, reached via a short bushwalk from the highway. The gabled nave, with black painted trusses extends to the south, while transepts contain the organ and vestry. The chancel, slightly elevated above the nave, is housed in an apse at the southern end of the church. In place of the conventional stainedglass windows or reredos, three large apsidal plate glass panels above the altar give views of the river, bridge, forest, and mountains beyond. As suggested by Awdry Julius, when the church was built and at times during its history, Franz Josef Glacier/Kā Roimata-aHinehukatere has also been visible through the altar glazing. ${ }^{9}$

The altar is draped with a blue cloth, with a simple cross placed centrally, flanked by two

\footnotetext{
${ }^{9}$ Lovell-Smith "St James Church" n.p.; "Church in the Alps" p 5.
}

brass candlesticks and two small brass vases. Plain blue carpet, blue kneelers and blue hymn books reference the blue-tinged ice of the glacier, while all the woodwork, including the pews, reading and prayer desks and railings, is painted black. The interior atmosphere of the church was described by Annie C Anderson in 1933:

The church is a consecrated effort of man to the glory of the great Master of the glacier. Inside, the softened blue light leads one's thoughts upward from the sanctity of the church itself to the beauty of the great window, a beauty not created by painted, nor stained-glass artist, a picture glorious and eternal, for the window mirrors the glacier itself. ${ }^{10}$

Anderson noted that the glacier scene was reflected in the glazed reredos when viewed from the exterior of the church, saying:

A full mountain panorama of blue sky, white clouds, snow-clad mountains, with nearer hills of tapestried forest, from summit to the glacier's foot, is mirrored. The wonderful reflection almost blots out the church's interior; one sees only the framing bush and the snowclad mountains. And entrancingly beautiful is the whole when seen on a moonlight night, for the light is gentle as the light of dreams. At evening service, with drawn blue curtains in the glow of the electric light, the

\footnotetext{
${ }^{10}$ Anderson "Waiho, Westland!" p 8.
} 
blue interior is, if possible, more ethereal, more beautiful than by day. ${ }^{11}$

Anderson believed that the church with its altar window was "surely unique ... not in New Zealand only, but in the whole world", 12 and it quickly gained international attention. A photograph of the framed view through the window was published in the August 1931 issue of Church News, ${ }^{13}$ and attracted approving comment. For instance, a cleric in Shanghai wrote to the Reverend Raymond Newcombe, the incumbent vicar in 1932, stating in respect of the window:

Permit me to say that I think the person who conceived the idea ... was inspired. The result shown in a photo I have received is amazingly beautiful, and must be a great aid to worship. ${ }^{14}$

Newspapers of the day were quick to report favourable opinion of the window, particularly from international dignitaries and visitors; the cultural cringe was in full swing! A Mr Hollister Sturges of New York was widely reported to have visited Franz Josef on his sixth world tour in 1932 and was said to be

\footnotetext{
${ }^{11}$ Anderson "Waiho, Westland!" p 8.

${ }^{12}$ Anderson "Waiho, Westland!" p 8.

${ }^{13}$ Lovell-Smith "St James Church" n.p.

14 "General news" p 8.
}

"much impressed" with the view from the window of the new church. ${ }^{15}$ When Sir Edward Heaton-Ellis, a British admiral who commanded HMS Inflexible at the Battle of Jutland, visited New Zealand in early 1933, he commented:

Both my wife and I think that the scenery in the Waiho Gorge and at the Franz Josef Glacier is among the finest we have ever seen ... The cleverness of the arrangement of the church at Waiho so that the Glacier forms the natural centrepiece of the altar window is remarkable. ${ }^{16}$

Prince Henry, Duke of Gloucester, the third son of King George V, visited Franz Josef Glacier on 8-9 January 1935, on his tour of New Zealand, staying overnight at the Grahams' hotel. He made two excursions onto the glacier, and after the second visited St James' Church, and saw "the famous view of the Glacier through its window."17 Newspaper reports of the visit stated:

By way of contrast between an oil painting and a cameo the party had an exhilarating spectacle presented from the glacier's terminal face and an exquisite view of the rata-mantled slopes was provided through the window of the little Anglican Church hidden in bush near the main track. Standing before the altar in the chapel the

\footnotetext{
15 "Franz Josef Glacier" p 8

16 "Fought at Jutland" p 5.

17 "The royal tour" p 12.
}

visitors saw the silhouette of a cross on the glacier's ice, so clear was the visibility. ${ }^{18}$

Sadly, the glacier retreated and was no longer visible through the altar window from about 1953. ${ }^{19}$ However, between 1985 and 2006, the glacier generally advanced and thickened, ${ }^{20}$ and it was once again able to be viewed from St James' for some years from about 1997.

\section{Church of the Good Shepherd, Lake Tekapo}

The need for a church at Lake Tekapo was first raised by the Reverend Walter Ernest Detheridge Davies in 1933, not long after his appointment as vicar of Fairlie. He discussed his idea with local parishioners, including the Murray family who were runholders of Godley Peaks and Glenmore stations, and suggested siting and orientating the church on the peninsula near the Tekapo bridge so that it could have a plate glass reredos behind the altar looking out at "the glorious and inspiring view" of lake and mountains, similar to Julius's idea for St James' at Franz Josef. Davies gained local support and subsequently also the approval of the Bishop of

\footnotetext{
18 "Duke climbs glaciers" p 3.

${ }^{19}$ Lovell-Smith "St James Church" n.p.

${ }^{20}$ McSaveney "Glaciers and glaciation" n.p.
} 
Christchurch, Campbell West-Watson, who had officiated at the opening of St James'. ${ }^{21}$

Esther Hope from Grampians Station, a wellknown artist, made drawings and a model, and Christchurch architect Richard Strachan De Renzy Harman drew up plans for the new church. The originally suggested site for the church was abandoned after the Public Works Department advised that Lake Tekapo was to be dammed and the lake level raised by nine metres, submerging the site. A new location was selected overlooking Lake Tekapo on land donated by the Murray family. ${ }^{22}$ In 1935, Peter Hope, a visitor from Great Britain, purchased the section adjacent to the church and gave it to the church trustees to preserve the view from the church window in perpetuity. ${ }^{23}$

In 1934, Fred Trott of Takapo House was engaged to construct the building, and he was assisted by Les Loomes, Doug Rodman and Christchurch stonemason Jack Miller. The

${ }^{21}$ Drake "The flock that built a church" n.p.; "Memorial church" p 12.

22 "Memorial church" p 12; Lovell-Smith "Church of the Good Shepherd" n.p.

23 "View from church window" p 10; "Church at Lake Tekapo" p 8. contract for the oak shingle roof was separately let to Mr Lorrimer of Christchurch. Construction had progressed sufficiently in time for the foundation stone to be laid by the Duke of Gloucester on 15 January 1935, just six days after he had visited St James' Church at Franz Josef/Waiau. The church was completed a few months later and was dedicated by Bishop West-Watson on 3 August. ${ }^{24}$ The first marriage in the new church was contracted between Doug Rodman and Peggy Trott, daughter of Fred Trott, later that year on 14 December. ${ }^{25}$

The church is a simple gable form constructed from poured concrete faced with local boulders. It sits on an axis just off northsouth, with the off-centre belfry and central entrance at the southern end. The northern end of the gable is surmounted by a concrete cross. The original oak shingle roof was replaced with slate in 1957. Harman designed the interior and its fittings, including the pews, communion rail, vicar's prayer desk and seat, with an Arts and Crafts aesthetic. The walls are rendered in cream plaster and the rimu roof timbers are stained dark.

${ }^{24}$ Drake "The flock that built a church" n.p.; "Memorial church" p 12.

25 "Wedding" p 12
Frederick Gurnsey of Christchurch carved the altar with a representation of the Good Shepherd, as well as the Oamaru stone font, lecturn and stand for the Book of Remembrance. ${ }^{26}$

Save for some tussocks and matagouri, the Church of the Good Shepherd stands isolated above Lake Tekapo, immersed in the same panoramic scene as viewed in framed miniature through the glazed reredos. The altar view is of the turquoise waters of the lake to the west of Motuariki to the snowcovered peaks of the Southern Alps/Kā Tiritiri o te Moana beyond. Today the church is said to be one of the most photographed buildings in New Zealand, attracting more than 100,000 tourists a year in the mid 2010s. Its popularity and disrespectful behaviour by visitors meant that the parish has banned photography inside the church. ${ }^{27}$

\section{Other examples of glazed altar windows}

Despite the success and attraction of the glazed windows behind the altars at St James' and the Church of the Good Shepherd, few other New Zealand churches emulate their

\footnotetext{
${ }^{26}$ Lovell-Smith "Church of the Good Shepherd" n.p. ${ }^{27}$ Downes "The "most photographed" places in New Zealand" n.p.
} 
design. The Church of the Ascension, in the Christchurch suburb of Mount Pleasant on a hill overlooking the Avon-Heathcote Estuary/ Te Ihutai, was completed in 1938. At its dedication, Bishop West-Weston compared the view from the window behind the altar at sunset to that seen at St James' and the Good Shepherd. ${ }^{28}$ The best-known later example is Paul Pascoe's stone-clad Arthur's Pass Chapel (1956), which has full-width glazed windows behind the altar, framing a view of the Avalanche Creek waterfall surrounded by native bush. ${ }^{29}$ Another modest example is the Rāhotu Wesley Church, on State Highway 45, in Taranaki. ${ }^{30}$ A domestic-scale bay window serves as the chancel and faces directly east to Taranaki Maunga.

\section{Discussion}

Bill McKay has seen the plate glass windows at St James', the Good Shepherd and Arthur's Pass as a metaphor for reforms in church liturgy during the first half of the twentieth century. At a time when churches were becoming less relevant to society, he suggests that the clear glazed altar windows could be seen as the church opening itself physically to

28 "New church at Mount Pleasant" p 8.

${ }^{29}$ McKay Worship p 111.

${ }^{30}$ Wood. Pers. comm. 14 September 2021. the outside world, making the external environment more apparent from within the church, and drawing the two closer together. ${ }^{31}$ He further suggests that the design of these churches may have been influenced by the role of landscape art at that time in the development of New Zealand's and New Zealanders' sense of place and identity. They could be seen as places of worship set in New Zealand's spectacular natural landscapes, rather than in England's green and pleasant land. ${ }^{32}$

While McKay's proposition of a metaphorical opening of the church to the outside world is an interesting one, it is possible that the choice of a glazed reredos for St James' Church, in particular, was equally a prosaic one. The initial design for the church by Guthrie had been rejected as being too expensive, and Dean Julius' suggestion of a plate glass altar window would have been attractive as a means of keeping costs down, compared with the alternatives of stained glass or a crafted, decorative reredos. Julius' motivation for his suggestion is unknown, but, as Archdeacon of Timaru and Westland from 1922, he visited

${ }^{31}$ McKay Worship pp 111, 145.

${ }^{32}$ McKay Worship pp 124-125. the area and would have known the Grahams as one of the leading families of Franz Josef/ Waiau. With the Grahams' association with the mountains and glaciers as guides, it would have been natural for Julius to propose a window onto the landscape of God's handiwork that shaped the lives of the church's congregation.

The siting of St James' within a bush clearing, with entry gained along a path fringed with tree-ferns, and the glacier and mountain view only serves to heighten the religious experience of worshipping at the church and is a metaphor for the Christian journey of spiritual growth, pilgrimage and coming to know the mystery of God. The view can only be appreciated by someone taking the time to enter the church and spend time there, and is not fully seen or understood by a mere passerby. Even the disappearance, then reappearance and subsequent disappearance of the glacier in the window as the ice has retreated, advanced and then retreated again can be seen as an allegory for the life, death and resurrection of Jesus, albeit one unintended by the church's designers. In this sense, the Good Shepherd is less successful. Its situation as an isolated building in an expansive landscape means that the view 
through the church's altar window is not unique and the same prospect can easily be gained from very many positions in the church's vicinity. There is little sense of spiritual journey or discovery when visiting the church, no matter how "glorious and inspiring" the altar view. In short, there is no mystery or revelation at the Church of the Good Shepherd. 


\section{REFERENCES}

Anderson, Annie C. "Waiho, Westland!" Evening Star (12 April 1933):8.

"Church at Lake Tekapo" The Press (26 July 1935):8.

"Church in the Alps" Hawera Star (1 May 1931):5.

Downes, Siobhan "The "most photographed" places in New Zealand" Stuff (1 August 2016).

https://www.stuff.co.nz/travel/destinations/nz/82565662/the-mostphotographed-places-in-new-zealand

Drake, Doug "The flock that built a church" Timaru Herald (29 April 2014). https://www.stuff.co.nz/timaru-herald/news/9987597/The-flock-thatbuilt-a-church

"Duke climbs glaciers" Stratford Evening Post (10 January 1935):3.

"Fought at Jutland" Christchurch Star (30 January 1933):5.

"Franz Josef Glacier" The Press (18 March 1932):8.

"General news" The Press (3 October 1932):8.

Lovell-Smith, Melanie "Church of the Good Shepherd" Heritage New Zealand (4 October 2002). https://www.heritage.org.nz/thelist/details/311

Lovell-Smith, Melanie "St James Church (Anglican)" Heritage New Zealand (3 June 2003). https://www.heritage.org.nz/the-list/details/4994

McKay, Bill Worship: a History of New Zealand Church Design New Zealand: Penguin Random House, 2015.

McSaveney, Ellen "'Glaciers and glaciation - Tasman, Franz Josef and Fox glaciers" Te Ara - the Encyclopedia of New Zealand, 2007.

https:/teara.govt.nz/en/photograph/10735/franz-josef-glacieradvances-and-retreats

"Memorial church" Timaru Herald (15 January 1935):12.

"New church at Mount Pleasant" The Press (24 October 1938):8.

Pope, Diana and Pope, Jeremy South Island and Stewart Island: Mobil New Zealand Travel Guide Wellington: Reed, 3rd revised edition, 1983.
"The royal tour" The Press (10 January 1935):12.

"Takapō" Kā Huru Manu Te Rūnanga o Ngāi Tahu. https://www.kahurumanu.co.nz/atlas

Taonui, Rāwiri "Canoe traditions - Canoes of the South Island" Te Ara the Encyclopedia of New Zealand, 2005: 8.

http://www.TeAra.govt.nz/en/canoe-traditions/page-8

"View from church" New Zealand Herald (10 May 1935):10.

Warren, Alwyn K. "Waiho Gorge church" The Press (29 April 1932):17.

"Wedding" Timaru Herald (16 December 1935):12.

"Whenua" Te Karaka (Kahuru/Autumn 2019):3.

https://ngaitahu.iwi.nz/our_stories/whenua-tk81/

Wood, Peter. Personal communication, email, 14 September 2021.

Yarwood, Vaughan "The cold hard truth" New Zealand Geographic (MayJune 2014) (127). https://www.nzgeo.com/stories/the-cold-hard-truth/ 